\title{
SOME ASPECTS OF EFFECTIVENESS IN HUNGARIAN-VIETNAMESE BUSINESS COMMUNICATION
}

\author{
ISTVAN LENART
}

\begin{abstract}
With the aim of revealing linguocultural gaps (lacunas) in Hungarian-Vietnamese business communication, a questionnaire-based study was conducted. A total of 638 questionnaires was completed and analysed. Participants of the survey were Vietnamese individuals who had lived and graduated from university in Hungary, and had a good command of the Hungarian language. In this presentation, the results obtained will be displayed, including linguistic and cultural differences between representatives of the two aforementioned nations. The theoretical background of the study is the Lacuna Theory, developed by the Moscow School of Ethnopsycholinguistics. The results of the survey will hopefully contribute to the further development of the Lacuna Theory in general and in the business context in particular.
\end{abstract}

Key words: Lacuna Theory, business communication, lacunas, culture-specific vocabulary, Moscow School of Ethnopsycholinguistics, association method, lacuna classification network, intercultural communication, verbal consciousness, Hungarian-Vietnamese comparison

The Moscow School of Ethnopsycholinguistics is scarcely present in Western scientific discourse on linguistics, intercultural communication, and psycholinguistics. It is a scientific and research field within the Moscow School of Psycholinguistics, and it heavily relies on the cultural-historical school of Vygotsky (Vygotsky, 1931), and the activity theory of A.A. Leontiev (Leontiev, 1974). Russian Psycholinguistics dates to 1966 (Ufimtseva, 2012), when A.A. Leontiev delivered his first lectures on psycholinguistics in Moscow, and it applies large-scale association experiments in order to study verbal/linguistic consciousness on both the individual and the national level. The area of Ethnopsycholinguistics was delineated from the 
discipline as an independent sub-field in the 1970s by the foundational works of Yuri Sorokin (Sorokin 1977) and Irina Markovina (Markovina, 1982). The Moscow School of Ethnopsycholinguistics, moreover, introduced the Lacuna Theory (Sorokin and Markovina, 1983) as a theoretical framework and investigation tool.

In our paper, we investigate Hungarian-Vietnamese business communication, based on the achievements of the Moscow School of Ethnopsycholinguistics: utilizing primarily the Lacuna Theory as a conceptual framework. A lacuna in the everyday meaning of the word is "a blank space", a "missing part", a "deficiency" or a "small cavity, pit, or discontinuity in an anatomical structure" (www.merriamwebster.com). If we observe the technical term lacuna, then we can state that lacunas are "phenomena of a culture that have no equivalents in another culture regarding both linguistic as well as cultural specifics" (Sorokin and Markovina, 1983).

In order to reveal such lacunas in the context of Hungarian-Vietnamese business communication, we conducted a questionnaire-based study. Respondents are Vietnamese citizens who had lived and graduated in Hungary, and have a good command of the Hungarian language. This paper aims at raising the effectiveness of Hungarian-Vietnamese business communication by identifying and analyzing linguistic and cultural lacunas, and sharing the results with the stakeholders of bilateral business (and other) relations. Secondly, we do hope to contribute to the development and the dissemination of the Lacuna Theory in the English-speaking academic world.

In order to maximize the number of lacunas identified, we developed a complex/mixed methodology, consisting of six individual, dissimilar questionnaires with different contents. These six thematic questionnaires dealt with the topics: (1) stereotypes; (2) case studies; (3) statements; (4) associations; (5) proverbs; (6) habits/lacunae. Due to space limitations, we will restrict ourselves to briefly introducing the method, highlighting some key results, and providing a handful of examples on lacunas.

The verb nhâu, identified in the study has the basic denotation: "consume alcoholic beverages" (www.en.glosbe.com); "to drink wine" (www.vdict.com); "to drink alcohol" or "to do drinking" (www.en.bab.la). In a wider sense, the term means "to booze" (Khang and Thanh, 1996), to carouse, or to have fun eating and drinking with friends (Kiem, 2015). The word is often used in syntagmatic structures such as đi nhậu (literally: "go drink") or ăn nhậu (literally: "eat drink"), implying that nhậu refers to an activity done together, in the company of friends. As revealed in our research Vietnamese understand $n h a ̣ ̂ u$ not only as a way of hanging out and drinking in the company of others, but also consider this social activity as a key instrument of doing business. A Vietnamese businessperson sees $n h \hat{a} u$ as a way to socialize with his/her potential business partner, learn more about him/her, and potentially make decisions on the spot (in contrast with several European countries, where a decision is usually made in the meeting room). The lack of this cultural-linguistic knowledge 
and this semantic gap (when i.e. contrasting the terms đi nhậu and go and drink), can lead to missed business chances.

Another curious example is the adjective khoa hoc. The dictionary meaning is "scientific" - or "science" when used as a noun (www.dict.com). Interestingly, when respondents were asked about the differences when living in Hungary compared to their lives in Vietnam, the second most frequently received answer claimed that life in Hungary was more "scientific" (khoa hoc). The Hungarian language user may have difficulties translating and understanding the term khoa hoc. Moreover, the Hungarian equivalent of the word (tudományos; scientific) would surely not be applied in a similar context in Hungary. In order to reveal the linguocultural dissimilarity, we need to learn that in the Vietnamese context the word "refers to a specific lifestyle connected to health and a theoretically correct way of living based on scientific facts" (Lenart 2016). Thus, in the business setting, Hungarians are seen as wellplanned, thorough and staid: more self-conscious than Vietnamese. This lacuna may also refer to different routines when planning a business deal, designing its steps, communication and acting in the business environment.

In the framework of our mixed methodology, we asked respondents to express their opinion on specific, concrete stories. The underlying concept of these case studies was Hungarian-Vietnamese cultural-linguistic misunderstandings. In one of the case studies, we investigated the expression "chị của tôi", which literally means "my elder sister". Chi is a kinship term in the Vietnamese language, often used in the role of personal pronouns. Its closest and most frequent Hungarian translation is növér (elder sister), which for the Hungarian language users definitely refers to a blood relation. Contrariwise, in the Vietnamese language and culture the term may refer to a close friend, whom Vietnamese have known for fairly long time, and whom they cherish and trust. As respondents worded it: "the reason of misunderstanding is lack of knowledge of Vietnamese addressing forms between younger and older: "chi của tôi" expresses respect, friendliness and creates trust" or "Vietnamese often consider their older close friends as their elder brother or sister. It doesn't mean that they are siblings" (Lenart, 2016: 63). We can state that the lacuna in question may cause serious misunderstandings both in general and in the business context.

Respondents were requested to finish sentences such as Hungarian businesspersons are... or Vietnamese businesspersons are..., enabling us to collect stereotypes about businessmen and businesswomen from the two countries and contrast the results.

Table 1 shows the different stereotypes gathered. A Hungarian businessperson is characterized by mainly positive features such as straight, intelligent, knowledgeable, professional and successful, while only one contradictory statement (being good/not good in catching opportunities/doing business) was recorded. On the other hand, Vietnamese businesspersons are described in both favourable and less favourable ways: as being dynamic, hard-working, at the same time short-sighted and ones that tend to evade taxes and not to abide by the law. 
Table 1. Stereotypes on Hungarian and Vietnamese businesspersons

\begin{tabular}{|c|l|l|}
\hline & \multicolumn{1}{|c|}{ Hungarian businesspersons } & \multicolumn{1}{c|}{ Vietnamese businesspersons } \\
\hline 1. & straight/downright & dynamic \\
\hline 2. & intelligent & hard-working/diligent \\
\hline 3. & not good at catching opportunities & $\begin{array}{l}\text { no long-term view and strategy/run after short- } \\
\text { term profits/short-sighted }\end{array}$ \\
\hline 4. & $\begin{array}{l}\text { able to do business very well } \\
\text { knowledgeable } \\
\text { professional } \\
\text { successful }\end{array}$ & $\begin{array}{l}\text { don't abide by the law/dodge the law/evade } \\
\text { taxes }\end{array}$ \\
\hline
\end{tabular}

Proverbs are rich imprints of cultures and furthermore can be adequate sources for identifying lacunas. For this reason, we collected Hungarian and Vietnamese proverbs: firstly, connected to money (thus investigating a business-related concept) and secondly, without any specific thematic restrictions. A total of 300 proverbs were collected, reflecting different values and approaches to life. The Vietnamese proverb Luật trước cho ngườ giàu, luật sau cho ngườ khó (One law for the rich, another for the poor), for example, displays the thought of social injustice; meanwhile, Tiền nào cũng là tiền (Any money is money) emphasizes the importance of thriftiness and of valuing money. Similarly, Hungarian proverbs reflect social values, e.g. Ki korán kel, aranyat lel (Who gets up early, finds gold) displays the virtue of industriousness; at the same time, the Hungarian proverb Pénz olvasva, asszony verve jó (Money is good when read, woman is good when beaten) reveals some practices unfortunately still strongly present in the Hungarian culture.

In Table 2 below we contrast the core values identified, based on the proverbs respondents evoked without specific thematic restrictions. We can see that some of the key Vietnamese values identified are communitarianism, solidarity, respect of teachers and the elderly, education, knowledge and egalitarianism. Meanwhile, Hungarian values are centered around family, the parent-child relationship, diligence at a new workplace, resistance to change and freedom.

Table 2. Values reflected by the proverbs

\begin{tabular}{|c|l|l|}
\hline & Values reflected by Hungarian proverbs & \multicolumn{1}{|c|}{ Values reflected by Vietnamese proverbs } \\
\hline 1. & Family & Communitarianism, solidarity \\
\hline 2. & Parent-child relationship & $\begin{array}{l}\text { Respect of teachers } \\
\text { Respect of the elderly }\end{array}$ \\
\hline 3. & Diligence at a new workplace & Respect of the elderly \\
\hline 4. & Difficulty/resistance to change & Education, knowledge \\
\hline 5. & Freedom & Communitarianism, egalitarianism \\
\hline
\end{tabular}


As a last point of our analysis, we chose a direct way to identify lacunas in the Vietnamese-Hungarian context: we asked the respondents straightforwardly to point out which of their habits they changed after returning from Hungary to Vietnam. These perceivable changes can substantially mark the presence of intercultural lacunas. In terms of verbal communication, we can state that the Vietnamese are more reluctant to say sorry or thank you than Hungarians (Table 3). When comparing behavioural discrepancies, we can observe that Hungarians are more punctual, more disciplined, honest and orderly. They are conscious of protection of the environment and tend to respect public regulations and abide by the law more typically than Vietnamese do.

Table 3. Changed habits

\begin{tabular}{|l|c|}
\hline \multicolumn{1}{|c|}{ Changed habits } & Frequency \\
\hline More punctual, arrive on time & 21 \\
\hline Conscious of protection of the environment & 14 \\
\hline Habit of saying thank you and sorry & 8 \\
\hline Abide by the law & 5 \\
\hline More careful & 4 \\
More disciplined & 4 \\
\hline Honesty & 3 \\
Orderliness & 3 \\
Respect public regulations & 3 \\
\hline
\end{tabular}

As a conclusion of our study, we can state that the Lacuna Theory proved to be a useful and effective approach of analysing Hungarian-Vietnamese business relations. We are convinced that revealing lacunas - markers of intercultural differences - can effectively help the better mutual understanding of Hungarians both in the business setting and in general. Furthermore, the method can be applied for several purposes not mentioned in this paper, including: the compilation of cultural dictionaries; assembling lacuna-based business manuals; the description of a culture by lacunae excerpted from artistic/literary texts; the research on networks of lacunae; intracultural lacunology; lacuna research through studying slang language.

\section{References}

Khang, N.V. and P.X. Thanh. 1996. Dictionary of common Vietnamese language. (Tu Dien Tieng Viet Thong Dung). Hanoi: Nhà Xuất Bản Giáo Dục.

Kiem, T.D. 2015. Vietnamese-Hungarian Dictionary. (Dai Tu Dien Viet-Hung). Budapest: Tran Dinh Kiem. 
Lenart, I. 2013. "How do Vietnamese and Hungarian businessmen communicate?” In: Nguyen Van Hiep (ed.). Hoi Thao Khoa Quoc Te Ngon Ngu Hoc Viet Nam trong Boi Canh Doi Moi va Hoi Nhap. International Conference on the Linguistics of Vietnam in the Context of Renovation and Integration. Hanoi. 60-61.

Lénárt, I. 2016. Intercultural lacunae in Hungarian-Vietnamese communication, with emphasis on entrepreneurial interactions. Doctoral dissertation. Budapest: Eotvos Lorand University.

Leontiev, A.A. 1974. Психология общения. (Psychology of communication). (Reprint: 1997. Moscow: Tartu).

Markovina, I. 1982. Влияние лингвистических и экстралингвистических факторов на понимание текста. (The influence of linguistic and extra-linguistic factors on text comprehension). CSc dissertation. Moscow.

Panasiuk, I. and H. Schröder (eds.). 2006. Lakunen-Theorie. Ethnopsycholinguistische Aspekte der Sprach- und Kulturforschung. Berlin: LIT Verlag.

Sorokin, Y. 1977. Национально-культурная специфика речевого поведения. (National-cultural specifics of speech activity). Моscow: Наука (Science).

Sorokin, Y. and I. Markovina. 1983. “Опыт систематизации лингвистических и культурологических лакун: методологические и методические аспекты”(“An attempt to classify linguistic and cultural lacunae: methodological and method-based aspects"). In Вомперский, В.П. (ed.). Лексические единицы и организация структуры литературного текста. (Lexical units and the organization of the structure of the literary text). Калинин (Kalinin): Калининский гос. ун-т: КГУ. 35-52.

Ufimtseva, N. 2012. "Culture as a system of consciousness". In Mininni, G. and A. Manuti (eds.). Applied psycholinguistics. Positive effects and ethical perspectives. Milano: FrancoAngeli. 74-82.

Vygotsky, L. 1931. "The history of the development of higher mental functions". In: Rieber, R.W. (ed.). The collected works of L.S. Vygotsky. Vol. 4. New York: Plenum Press. 